\title{
AGRP wt Allele
}

National Cancer Institute

\section{Source}

National Cancer Institute. AGRP wt Allele. NCI Thesaurus. Code C115167.

Human AGRP wild-type allele is located in the vicinity of $16 \mathrm{q} 22$ and is approximately $1 \mathrm{~kb}$ in length. This allele, which encodes agouti-related protein, is involved in the regulation of feeding behavior. Mutation of the gene is associated with obesity. 